\title{
GC-FID METHODOLOGY VALIDATION FOR THE FATTY ESTERS CONTENT DETERMINATION IN BIODIESEL WITH HEXADECYL ACETATE AS THE INTERNAL STANDARD
}

João V. Braun, ${ }^{\mathrm{a}, \mathrm{b}}$ Vinícius O. B. dos Santos, ${ }^{\mathrm{a}, \mathrm{b}}$ Luiz A. M. Fontoura, ${ }^{\mathrm{a}, \mathrm{b}, *}$ Evandro Pereira, ${ }^{\mathrm{c}}$ Amanda Napp, ${ }^{\mathrm{c}}$ Marcus Seferin, ${ }^{\mathrm{d}}$ Jeane Lima, ${ }^{d}$ Rosane Ligabue $^{\mathrm{d}}$ e Marilene H. Vainstein ${ }^{c}$

aDepartamento de Engenharia de Processos, Fundação de Ciência e Tecnologia, Av. das Indústrias 2270, 94930-230 Cachoeirinha - RS, Brasil

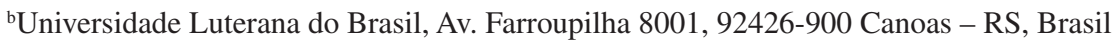

${ }^{\mathrm{c} C e n t r o ~ d e ~ B i o t e c n o l o g i a, ~ U n i v e r s i d a d e ~ F e d e r a l ~ d o ~ R i o ~ G r a n d e ~ d o ~ S u l, ~ A v . ~ B e n t o ~ G o n c ̧ a l v e s ~ 9500, ~ 91501-970 ~ P o r t o ~ A l e g r e ~-~ R S, ~}$ Brasil

'Faculdade de Química, Pontifícia Universidade Católica do Rio Grande do Sul, Av. Ipiranga 6681, Prédio 12, 90619 -900 Porto Alegre - RS, Brasil

Recebido em 05/01/2017; aceito em 31/05/2017; publicado na web em 03/08/2017

\begin{abstract}
Biodiesel purity expressed as fatty esters content is one of its most important quality parameters. Although several instrumental methods have been employed, gas chromatography with internal standard calibration has been the most used. Biodiesel is a very complex matrix, therefore finding a suitable internal standard (IS) is not straightforward. EN14103:2003 standard established methyl heptadecanoate (C17:0) as IS. Since this fatty ester is naturally present in some biodiesel feedstock as tallow, that standard was reviewed in 2011, and methyl nonadecanoate (C19:0) became the new IS. In turn, C19:0 produces a peak on the chromatogram that is difficult to resolve from methyl linoeate (C18:2) and metyl linolenate (C18:3) ones. In this paper, a GC-FID method for the determination of the esters content in methyl and ethyl biodiesel from canola and soy oils, using hexadecyl acetate as a new internal standard was validated. EN14103:2003 was used as reference method. Method selectivity, accuracy $(t$ student parameter $<2.18$ from both methods), repeatability $(0.1-0.4 \%)$, intermediate precision $(0.2-1.8 \%)$, and robustness $(0.1-1.6 \%)$ were investigated and considered appropriate for the scope.
\end{abstract}

Keywords: biodiesel; gas chromatography; fatty esters; hexadecyl acetate.

\section{INTRODUCTION}

Since the industrial revolution of $19^{\text {th }}$ century, and even today, fossil fuels as coal and oil derivatives have been the major sources of energy. In 2015, fossil sources represented $85 \%$ of the world energy consumption. ${ }^{1}$ Brazil has a diversified energetic matrix, but the same sources still contributes about $60 \%$. The transportation system, in particular, depends heavily on gasoline and diesel, and only $21 \%$ of the consumed fuel in the country was renewable in $2015 .^{2}$

Concerns on geographic, politics, and economic factors associated with oil scarcity, environment preservation and sustainable development, have driven society in search for alternative and renewable energetic sources, especially those derived from the biomass..$^{3-6}$ As a reaction to the oil crises in $70 \mathrm{~s}$, Brazil introduced ethanol as substituted for gasoline. More recently, in 2008, the addition of biodiesel to diesel became mandatory. ${ }^{7-9}$ In 2016, Brazilian production of biodiesel was 3.8 million of $\mathrm{m}^{3},{ }^{10}$ turning Brazil to the second major producer in the world. ${ }^{11}$ As a fuel, biodiesel has several advantages compared to diesel. It is environmental friendly, free from sulfur compounds and aromatics, biodegradable, and renewable. It stimulates the rural development and agriculture, and can contribute to decrease of oil importation. In addition, biodiesel has better proprieties, such as the higher cetane number, flash point, and lubricity. ${ }^{12-15}$

Biodiesel is a mixture of different fatty esters obtained by triglycerides transesterification or fatty acids esterification, Scheme 1.

Both rotes are alcoholise reactions. Methanol is the most used alcohol, nevertheless ethanol can also be employed. Triglycerides, or triacylglycerols, are the main components of oils and fats. ${ }^{14,15}$

*e-mail: 1mazzini@uol.com.br
Technically, most commercial oils and fats, including soy, canola, corn, sunflower, cotton, palm, tallow and lard can be used. ${ }^{15,16}$ In Brazil, soy oil and bovine tallow are the most important feedstock<smiles>[R]C(=O)OCC(COC([R])=O)OC([R])=O</smiles>

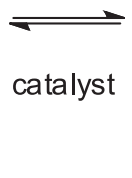<smiles>[R]OC([R])=O</smiles><smiles>[B]</smiles><smiles>[Z17]OC([R])=O</smiles><smiles>[R]C([R])=O</smiles>

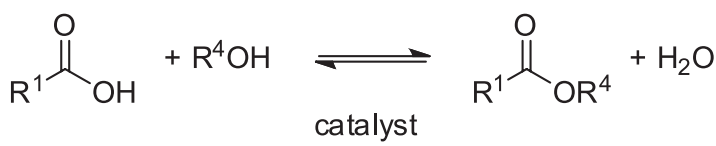

$$
\begin{aligned}
& \mathrm{R}^{1}, \mathrm{R}^{2}, \mathrm{R}^{3}=\text { alkyl or alkenyl long chain } \\
& \mathrm{R}^{4}=\mathrm{Me} \text { or } \mathrm{Et}
\end{aligned}
$$

Scheme 1. Biodiesel obtainment by triglycerides transesterification (superior) and fatty acids esterification (inferior) 
to the biodiesel production. ${ }^{17}$ Free fatty acids or those found in triglycerides show singular features. In general, their chains are linear and have an even number of carbons. When a double bond is present, it has cis configuration. In the case of polyunsaturated chains, the double bonds are not conjugated, that is, they are separated by a methylene group. ${ }^{18}$

The most abundant fatty acids are palmitic (C16:0), stearic (C18:0), oleic (C18:1), and linoleic (C18:2), Figure 1. In the CX:Y notation, $\mathrm{X}$ is the number of carbons, and $\mathrm{Y}$, the number of double bonds..$^{15,16,18}$

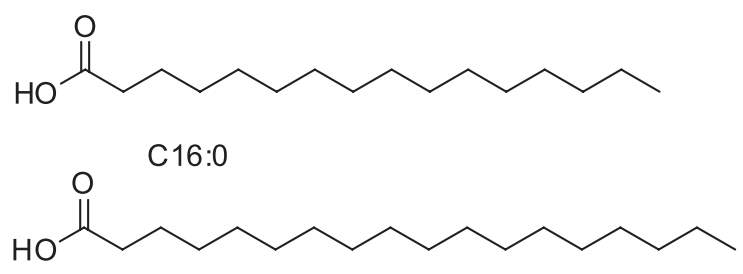

C18:0

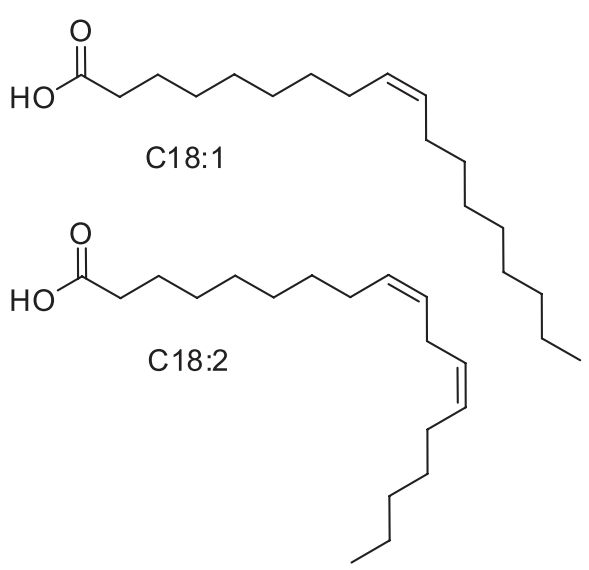

Figure 1. Common fatty acids: palmitic (C16:0); estearic (C18:0); oleic (C18:1); linoleic (C18:2)

Examples of methyl biodiesels from different sources are presented in Table $1 .{ }^{16}$

Biodiesel must be in accordance with a set of quality parameters to be employed, that includes purity and impurities contents; performance characteristics, as cetane number, oxidative stability; and physical properties, as viscosity, and specific mass. ${ }^{19}$ The purity of biodiesel is expressed as esters content, and can be estimated by several instrumental techniques, as gas chromatography-flame ionization detector (GC-FID), ${ }^{20-39}$ gas chromatography-mass selective detector (GC-MSD), ${ }^{22,38,40-46}$ high performance liquid chromatography-evaporative light scattering detector (HPLC-ELSD), ${ }^{22-25,47,48}$ high performance liquid chromatography-refractive index detector (HPLCRID) ${ }^{49}$ high performance liquid chromatography-variable wavelength detector (HPLC-VWD), ${ }^{23,32,34}$ gel permeation chromatography (GPC), ${ }^{23}$ high performance thin layer chromatography (HPTLC), ${ }^{50}$ nuclear magnetic resonance (NMR), ${ }^{23-25,30,36,45,51-53}$ termogravimetric analysis (TGA), ${ }^{30}$ and infrared spectroscopy (IR). ${ }^{25}$

Officially, it is quantified by gas chromatography with flame ionization detector (GC-FID) and internal standard, following the orientations of EN 14103. ${ }^{20}$ At first, methyl heptadecanoate (C17:0) was indicated as internal standard. Biodiesel made from some feedstock as tallow, nevertheless, contains C17:0 in its composition. In 2011, methyl nonadecanoate (C19:0) was introduced as a substitute for $\mathrm{C} 17: 0$. Retention times $\left(\mathrm{t}_{\mathrm{R}}\right)$ of $\mathrm{C} 19: 0, \mathrm{C} 18: 2$, and $\mathrm{C} 18: 3$, are too close, and the lack of resolution is sometimes observed. Several alternatives for ester content determination by GC have been presented in the literature. Some of them are listed in Table 2.

There are some conditions and desirable characteristics in order to use a substance as internal standard in chromatography: it has to be absent in the sample, to present a retention close to the analyte, to generate a similar detector response, and, evidently, must produce a well resolved peak on the chromatogram. The internal standard method has the advantages of being less susceptible to errors from injection, instrument instability, or sample preparation..$^{31,54,55}$ Flame ionization detector is suitable to the determination of organic compounds, producing linear signals to a wide range of concentrations, and low detection limit. Signal is generated from the carbon atoms ionization, and the intensity is proportional to the sample mass. The presence of heteroatoms, however, cause reduction on the sensibility. ${ }^{54}$ Esters obtained from short chain carboxylic acids with appropriate fatty alcohols present the same function, with similar structure and molecular formula to the fatty esters found in biodiesel, differing only by the inversion of acyl and alkyl groups. Hexadecyl acetate (HDA), for example, is a methyl heptadecanoate (C17:0) isomer, and presents the necessary requisites to be proposed as an internal standard for the biodiesel esters content determination.

The aim of this paper was the validation of an analytical method using GC-FID to estimate the biodiesel esters content employing hexadecyl acetate (HDA) as internal standard. Methyl and ethyl biodiesel from soy and canola oils were assayed. The following parameters were evaluated: selectivity, accuracy, repeatability, intermediate precision, and robustness.

Table 1. Methyl fatty ester content in biodiesel $(\%)^{16}$

\begin{tabular}{lccccccccc}
\hline biodiesel & C14:0 & C16:0 & C16:1 & C17:0 & C18:0 & C18:1 & C18:2 & C18:3 & others \\
\hline grape seed & 0.0 & 7.1 & 0.1 & 0.0 & 3.4 & 20.9 & 66.0 & 0.6 & 2.0 \\
soy & 0.1 & 10.5 & 0.1 & 0.0 & 2.0 & 24.9 & 53.4 & 4.6 & 4.6 \\
rice & 0.2 & 21.3 & 0.1 & 0.0 & 1.2 & 36.7 & 37.2 & 1.2 & 2.1 \\
canola & 0.1 & 4.8 & 0.2 & 0.0 & 1.3 & 64.5 & 20.9 & 5.2 & 3.0 \\
corn & 0.0 & 11.9 & 0.1 & 0.0 & 1.2 & 35.9 & 49.3 & 0.0 & 1.6 \\
palm & 0.9 & 41.6 & 0.1 & 0.1 & 3.2 & 41.5 & 12.0 & 0.2 & 0.5 \\
lard & 1.3 & 22.6 & 3.5 & 0.5 & 9.2 & 41.8 & 17.4 & 0.5 & 3.2 \\
tallow & 3.2 & 25.2 & 3.6 & 1.2 & 15.7 & 42.0 & 0.8 & 0.6 & 7.6 \\
peanut & 0.1 & 8.3 & 0.0 & 0.0 & 0.5 & 62.4 & 21.9 & 0.7 \\
olive & 0.1 & 6.6 & 0.1 & 0.0 & 2.9 & 33.8 & 55.0 & 0.2 & \\
\hline
\end{tabular}


Table 2. Fatty esters used as internal standard in GC esters content determination methods

\begin{tabular}{|c|c|c|c|}
\hline internal standard & feedstock & standardization & Ref. \\
\hline methyl undecanoate (C11:0) & olive, sunflower, rape, corn & internal & 37 \\
\hline methyl lauriate (C12:0) & tallow, waste cooking oil & internal & $26,27,29$ \\
\hline methyl myristate (C14:0) & soy, canola, corn, sunflower & internal & 39 \\
\hline methyl pentadecanoate $(\mathrm{C} 15: 0)$ & $\begin{array}{l}\text { corn, sunflower, soyabean, rapeseed, peanut, coconut, castor, cotton, linseed, } \\
\text { neem, waste cooking oil, microalgae }\end{array}$ & internal & 40 \\
\hline methyl stearate (C18:0) & tallow, lard, castor, palm, coconut, chicken and swine fats & external & $21,32,35$ \\
\hline ethyl oleate (C18:1) & soy & internal & 31 \\
\hline ethyl tricosanoate (C23:0) & linseed, tallow, soy, palm, sunflower, canola & internal & 28,33 \\
\hline
\end{tabular}

\section{EXPERIMENTAL}

Biodiesel obtainment: the biodiesel samples were obtained by transesterification double steps process (TDSP) as described by Samios et al..$^{52,53}$

Internal standard stock solutions: $c a 100 \mathrm{mg}$ of hexadecyl acetate (HDA, CBiot, $100.0 \%$ ) were accurately weighed, dissolved in heptane (Vetec), and diluted to $50 \mathrm{~mL}$ in a volumetric flask, to make a $2 \mathrm{mg} \mathrm{mL}^{-1}$ solution. The procedure was repeated to prepare methyl heptadecanoate (C17:0, Fluka 99.9\%) stock solution.

Biodiesel analytical samples: $c$ a $50 \mathrm{mg}$ of biodiesel were accurately weighed in a $10 \mathrm{~mL}$ flask, and dissolved in $5.0 \mathrm{~mL}$ of hexadecyl acetate stock solution measured in a $5 \mathrm{~mL}$ volumetric pipet, to make a $10 \mathrm{mg} \mathrm{mL}^{-1}$ solution. Seven replicates were prepared (HDA set). The procedure was repeated with methyl heptadecanoate stock solution (C17:0 set).

Chromatographic analyses: analyses were performed in a Shimadzu 2010 gas chromatography equipped with a flame ionization detector, AOC 20i auto-sampler and OV CARBOWAX 20 M (30 m x $320 \mu \mathrm{m}$ x $0.25 \mu \mathrm{m}$ ). First, the oven was set at $40{ }^{\circ} \mathrm{C}$ for $2 \mathrm{~min}$. Then, it was heated at $10{ }^{\circ} \mathrm{C} \mathrm{min}-1$ up to $230{ }^{\circ} \mathrm{C}$ and kept for $7 \mathrm{~min}$ (total run time $29 \mathrm{~min}$ ). A volume of $1 \mu \mathrm{L}$ was automatically injected in split mode (20:1). He was used as carrier gas at flow rate of $2.5 \mathrm{~mL} \mathrm{~min}^{-1}$. EN 14103 with $\mathrm{C} 17: 0$ as internal standard was used as reference method. Chromatograms were integrated between $\mathrm{C} 8: 0$ and $\mathrm{C} 24: 1$ peaks range. ${ }^{25}$ Each biodiesel sample solution was injected three times.

Purity: fatty esters content was estimated from the mean of each internal standard seven replicates set results. The purity, expressed as fatty esters content $\left(\mathrm{C}_{\mathrm{BD}}\right)$, was obtained as the average of seven replicates by equation $1,{ }^{20}$

$$
C_{B D}=\frac{\left(A_{t}-A_{I S}\right)}{A_{I S}} \times \frac{C_{I S} \times V_{I S}}{W}
$$

where $A_{t}$ is the total peak area, $A_{I S}$ is the peak area of the internal standard, $C_{I S}$ is the concentration of the internal standard solution / $\mathrm{mg} \mathrm{mL}{ }^{-1}, V_{I S}$ is the volume of the internal standard solution $/ \mathrm{mL}$, and $W$ is the weight of the sample / $\mathrm{mg}$

Accuracy: the method comparison using EN 14103:2003 with methyl heptadecanoate internal standard as reference was used to evaluate accuracy. Variances from the esters content obtained from the dual seven replicate sets (HDA and C17:0 sets) were compared by the Fischer test and the average ester content by $t$-test (12 degrees of freedom and $95 \%$ confidence interval). ${ }^{56}$

Selectivity: samples solutions in heptane with no internal standard were also prepared and injected to evaluate the selectivity.

Instrumental precision: area $(A)$ and retention times $\left(t_{R}\right)$ measurements of eight consecutive injections of a methyl and ethyl soy biodiesel solutions were obtained. Instrumental precision was expressed as $A$ and $t_{R}$ relative standard deviations (RSD).

Repeatability: the seven replicates from HDA set were analyzed. Repeatability was expressed as ester content relative standard deviations from the seven replicates.

Intermediate precision: three sets of four replicates were prepared by three different analysts and had their esters contents estimated. Intermediate precision was expressed as the ester content relative standard deviations from the means of each set.

Robustness: Youden Test was used to evaluate the robustness. ${ }^{57}$ The parameters chosen include injector temperature (248 and 250 $\left.{ }^{\circ} \mathrm{C}\right)$, detector temperature $\left(248\right.$ and $\left.250{ }^{\circ} \mathrm{C}\right)$, linear velocity (38 and $\left.40 \mathrm{~cm} \mathrm{~s}^{-1}\right)$, split (20 and 22:1), injection volume (0.9 and $\left.1 \mu \mathrm{L}\right)$, and initial oven temperature $\left(38\right.$ and $\left.40{ }^{\circ} \mathrm{C}\right)$.

Excluding the instrument precision, all other experiments were performed with three injections of every replicate.

\section{RESULTS AND DISCUSSION}

Chromatograms were integrated in the range from caprilate (C8:0) to nervonate (C24:1) peaks. Figure 2 presents detail from methyl and ethyl canola biodiesel, and the first one spiked with C17:0, C19:0, or HDA.

The chromatograms superposition assures the method selectivity. Biodiesel total area is the sum of its individual components peak area. As all their sensibility is assumed as equal, that is, all components present the same response factor, peak areas can be added even though they are overlapped. Internal standard peak, in contrast, must to be well resolved to be integrated. ${ }^{20}$ Fatty esters peaks were identified by their retention times $\left(t_{R}\right)$ compared to the ones obtained from authentic standards. C16:0 and C16:1 peaks are coeluted. The same is observed for C18:0 and C18:1. Hexadecyl acetate and methyl heptadecanoate produce well resolved peaks at 16.1 and $16.3 \mathrm{~min}$ respectively (Figure $2 \mathrm{~d}$ and $2 \mathrm{e}$ ). It can be noticed, on the other hand, that $\mathrm{C} 19: 0$ and $\mathrm{C} 18: 3$ peaks are unresolved on the methyl biodiesel chromatogram (Figure 2c). Whatever the biodiesel, that is, ethyl (Figure 2a) or methyl (Figure 2b), HDA closest peak is that of C16:0. In the first case, resolution ${ }^{58}$ is 1.6 , and 4.2 for the second.

The peaks retention times and areas relative standard deviation (RSD) were used to evaluate instrumental repeatability (Table 3). One sample solution of soy methyl biodiesel was injected 8 times. The peaks of palmitate (C16:0), hexadecyl acetate (HDA), and oleate (C18:1) were chosen. Instrumental repeatability was expressed as the relative standard deviation. Values equal or lower than $0.01 \%$ to the retention times measurements, and $0.98 \%$ to areas were observed, and considered adequate. ${ }^{55,58,59} \mathrm{~A}$ dispersion close to zero on the retention times measurements ensure the standard peak resolution maintenance. Integral low dispersion, by its turn, contributes to minimize quantitative analysis errors. 


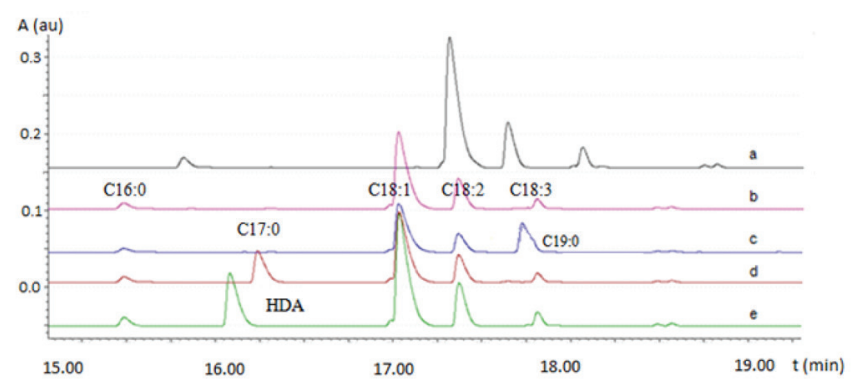

Figure 2. Canola biodiesel chromatograms: ethyl (a), methyl (b), methyl spiked with C19:0 (c), methyl spiked with C17:0 (d), and methyl spiked with HDA (e)

The ester contents of four different biodiesel samples were determined. In each case, seven replicates were prepared and analyzed by the same analyst. Two different internal standards were used, HDA and C17:0. Precision is the degree of agreement among individual test results. Method precision was evaluated in two levels, repeatability (same operation conditions and short period of time), and intermediate precision (same operation conditions, but different analysts). Table 4 presents the esters contents from the seven replicates, their means, and the repeatability expressed as relative standard deviation (RSD). Repeatability values less than $2 \%$ were found and considered adequate..$^{55,58,59}$

In order to estimate the intermediate precision (IP), three different analysts prepared four replicates sets. The results are presented in Table 5. Each set had its ester content mean value calculated (P). IP was calculated as the relative standard deviation obtained from the three analysts' mean values $\left(\mathrm{P}_{\mathrm{A}}\right)$. IP values less than $2 \%$ were found and considered adequate. ${ }^{55,58,59}$

Accuracy is the closeness of a measured value to the true value. ${ }^{55,58,59}$ In this study, accuracy was obtained by method comparison. EN14103:2003, which uses C17:0 as the internal standard, was used as reference methodology. Fatty esters contents $\left(\mathrm{P}_{\mathrm{HDA}}\right.$ and $\left.\mathrm{P}_{\mathrm{C} 17: 0}\right)$ are presented in Table 6 , and expressed at $95 \%$ confidence interval. A range from 94.8 to 100.8 was found. Calculated $F$ parameters are lower than the critical value (4.28), which means that the two methods have no variance difference. Student's $t$

Table 3. Instrumental repeatability: retention times $\left(t_{R}\right)$ and peak areas $(A)$

\begin{tabular}{|c|c|c|c|c|}
\hline & \multicolumn{2}{|c|}{ soy methyl biodiesel } & \multicolumn{2}{|c|}{ soy ethyl biodiesel } \\
\hline & $t_{R}(\min )$ & A (a.u.) & $t_{R}(\min )$ & A (a.u.) \\
\hline & mean (RSD) & mean (RSD) & mean (RSD) & mean (RSD) \\
\hline $\mathrm{C} 16: 0$ & $15.56(0.01)$ & $848849(0.60)$ & $15.84(0.00)$ & $1042453(0.89)$ \\
\hline HDA & $16.15(0.01)$ & $2557662(0.69)$ & $16.15(0.01)$ & $2538266(0.89)$ \\
\hline C18:1 & $17.12(0.01)$ & $1984019(0.66)$ & $17.38(0.01)$ & $2642560(0.98)$ \\
\hline
\end{tabular}

Table 4. Precision: feedstock (TG), ester (alkyl), internal standard (IS), replicates esters contents $\left(\mathrm{P}_{\mathrm{i}}\right)$, sample's mean ( $\mathrm{P}_{\text {mean }}$ ), and repeatability (R)

\begin{tabular}{lccccccccccc}
\hline TG & alkyl & IS & $\mathrm{P}_{1}$ & $\mathrm{P}_{2}$ & $\mathrm{P}_{3}$ & $\mathrm{P}_{4}$ & $\mathrm{P}_{5}$ & $\mathrm{P}_{6}$ & $\mathrm{P}_{7}$ & $\mathrm{P}_{\text {mean }}$ & $\mathrm{R}(\%)$ \\
\hline canola & $\mathrm{Me}$ & $\mathrm{HDA}$ & 96.5 & 94.9 & 94.9 & 94.8 & 96.6 & 96.2 & 95.8 & 95.7 & 0.83 \\
canola & $\mathrm{Me}$ & $\mathrm{C} 17: 0$ & 93.0 & 95.8 & 94.4 & 95.1 & 96.3 & 94.4 & 94.6 & 94.8 & 1.14 \\
canola & $\mathrm{Et}$ & $\mathrm{HDA}$ & 101.3 & 100.3 & 101.8 & 98.4 & 100.9 & 100.3 & 101.6 & 100.7 & 1.15 \\
canola & $\mathrm{Et}$ & $\mathrm{C} 17: 0$ & 101.2 & 101.1 & 99.9 & 101.3 & 101.4 & 100.8 & 99.8 & 100.8 & 0.66 \\
soy & $\mathrm{Me}$ & $\mathrm{HDA}$ & 98.3 & 97.7 & 97.9 & 96.6 & 98.5 & 97.5 & 97.5 & 97.7 & 0.63 \\
soy & $\mathrm{Me}$ & $\mathrm{C} 17: 0$ & 97.8 & 96.6 & 98.6 & 97.5 & 97.7 & 98.6 & 97.0 & 97.7 & 0.78 \\
soy & $\mathrm{Et}$ & HDA & 97.2 & 95.5 & 97.5 & 97.6 & 97.8 & 97.1 & 97.5 & 97.2 & 0.79 \\
soy & $\mathrm{Et}$ & $\mathrm{C} 17: 0$ & 95.8 & 95.7 & 96.5 & 97.4 & 96.6 & 95.9 & 96.9 & 96.4 & 0.66 \\
\hline
\end{tabular}

Table 5. Intermediate precision (IP): feedstock (TG), ester (alkyl), analyst (A), replicates esters contents $\left(\mathrm{P}_{\mathrm{i}}\right)$, analysts' mean $\left(\mathrm{P}_{\mathrm{A}}\right)$, and samples' mean $\left(\mathrm{P}_{\text {mean }}\right)$

\begin{tabular}{|c|c|c|c|c|c|c|c|c|c|}
\hline TG & alkyl & A & $\mathrm{P}_{1}$ & $\mathrm{P}_{2}$ & $\mathrm{P}_{3}$ & $\mathrm{P}_{4}$ & $\mathrm{P}_{\mathrm{A}}$ & $\mathrm{P}_{\text {mean }}$ & IP \\
\hline \multirow[t]{3}{*}{ canola } & $\mathrm{Me}$ & $\mathrm{A}_{1}$ & 101.3 & 100.3 & 101.8 & 98.2 & 100.4 & & \\
\hline & & $\mathrm{A}_{2}$ & 99.2 & 96.0 & 95.8 & 97.2 & 97.0 & & \\
\hline & & $\mathrm{A}_{3}$ & 98.9 & 97.1 & 98.9 & 95.8 & 97.7 & 98.4 & 1.8 \\
\hline \multirow[t]{3}{*}{ canola } & Et & $\mathrm{A}_{1}$ & 96.5 & 94.9 & 94.9 & 94.5 & 95.2 & & \\
\hline & & $\mathrm{A}_{2}$ & 91.3 & 95.7 & 94.5 & 93.6 & 93.8 & & \\
\hline & & $\mathrm{A}_{3}$ & 94.3 & 95.9 & 95.4 & 94.5 & 95.0 & 94.7 & 0.8 \\
\hline \multirow[t]{3}{*}{ soy } & $\mathrm{Me}$ & $\mathrm{A}_{1}$ & 95.4 & 100.2 & 100.3 & 98.5 & 98.6 & & \\
\hline & & $\mathrm{A}_{2}$ & 95.5 & 97.8 & 97.7 & 97.7 & 97.2 & & \\
\hline & & $\mathrm{A}_{3}$ & 98.3 & 97.7 & 97.9 & 96.7 & 97.7 & 97.8 & 0.8 \\
\hline \multirow[t]{3}{*}{ soy } & Et & $\mathrm{A}_{1}$ & 95.9 & 94.3 & 96.3 & 96.3 & 95.7 & & \\
\hline & & $\mathrm{A}_{2}$ & 97.4 & 93.5 & 94.4 & 96.2 & 95.4 & & \\
\hline & & $\mathrm{A}_{3}$ & 98.0 & 94.4 & 95.1 & 95.9 & 95.8 & 95.6 & 0.2 \\
\hline
\end{tabular}


Table 6. Accuracy: esters content from methyl heptadecanoate $\left(\mathrm{P}_{\mathrm{C} 17: 0}\right)$ and hexadecyl acetate $\left(\mathrm{P}_{\mathrm{HDA}}\right)$ methods, Fisher $(F)$ and Student $(t)$ parameters

\begin{tabular}{lccccc}
\hline & & $\mathrm{P}_{\mathrm{C} 17: 0}(\%)^{\mathrm{a}}$ & $\mathrm{P}_{\mathrm{HDA}}(\%)^{\mathrm{a}}$ & $\mathrm{F}$ & $\mathrm{t}$ \\
\hline canola & $\mathrm{Me}$ & $94.8 \pm 1.1$ & $95.7 \pm 0.7$ & 1.87 & 3.05 \\
canola & $\mathrm{Et}$ & $100.8 \pm 0.7$ & $100.7 \pm 1.2$ & 1.77 & 0.20 \\
soy & $\mathrm{Me}$ & $97.8 \pm 0.7$ & $97.7 \pm 0.6$ & 9.55 & 0.08 \\
soy & $\mathrm{Et}$ & $96.4 \pm 0.6$ & $97.2 \pm 0.7$ & 1.44 & 2.05 \\
\hline
\end{tabular}

a $95 \%$ confidence interval.

Table 7. Youden test - methyl $\left(\mathrm{P}_{\mathrm{Me}}\right)$ and ethyl $\left(\mathrm{P}_{\mathrm{E}}\right)$ biodiesel fatty esters content and the chromatographic conditions: injector temperature $\left(\mathrm{T}_{\mathrm{i}}\right)$, detector temperature $\left(\mathrm{T}_{\mathrm{D}}\right)$, linear velocity $\left(\mathrm{v}_{\mathrm{L}}\right)$, split ratio, injected volume $(\mathrm{V})$, oven final temperature $\left(\mathrm{T}_{\mathrm{F}}\right)$, samples' mean $\left(\mathrm{P}_{\text {mean }}\right)$, standard deviation $(\mathrm{s})$, and robustness $\left(\mathrm{R}_{\mathrm{o}}\right)$

\begin{tabular}{lccccccccccc}
\hline experiment & 1 & 2 & 3 & 4 & 5 & 6 & 7 & 8 & $\mathrm{P}_{\text {mean }}(\%)$ & $\mathrm{s}$ & $\mathrm{R}_{\mathrm{o}}(\%)$ \\
\hline $\mathrm{P}_{\mathrm{Me}}$ & 97.3 & 97.6 & 98.5 & 97.1 & 97.2 & 97.3 & 95.1 & 98.3 & 97.3 & 1.0 & 1.1 \\
$\mathrm{P}_{\mathrm{Et}}$ & 98.4 & 98.4 & 98.5 & 98.4 & 98.3 & 98.7 & 98.4 & 98.2 & 98.4 & 0.1 \\
$\mathrm{~T}_{\mathrm{i}}\left({ }^{\circ} \mathrm{C}\right)$ & 248 & 248 & 248 & 248 & 250 & 250 & 250 & 250 & 0.1 \\
$\mathrm{~T}_{\mathrm{D}}\left({ }^{\circ} \mathrm{C}\right)$ & 248 & 248 & 250 & 250 & 248 & 248 & 250 & 250 & \\
$\mathrm{~V}_{\mathrm{L}}\left(\mathrm{cm} \mathrm{s}^{-1}\right)$ & 38 & 40 & 38 & 40 & 38 & 40 & 38 & 40 & \\
$\mathrm{split}$ & 22 & 22 & 22 & 22 & 20 & 20 & 20 & 20 & \\
$\mathrm{~V}(\mu \mathrm{L})$ & 0.9 & 1.0 & 0.9 & 1.0 & 1.0 & 0.9 & 1.0 & 0.9 & \\
$\mathrm{~T}_{\mathrm{F}}\left({ }^{\circ} \mathrm{C}\right)$ & 248 & 250 & 250 & 248 & 248 & 250 & 250 & 248 & \\
\hline
\end{tabular}

parameters were calculated and were also found lower than the critical value $(2.18) .{ }^{56}$

Robustness is a measurement of the method capacity to remain unaffected by small parameters variations. ${ }^{57}$ In this study, Youden test was applied to methyl and ethyl soy biodiesel sample solutions in the presence of HDA as internal standard. Six factors were combined in eight experiments. Injector $\left(\mathrm{T}_{\mathrm{i}}\right)$, and detector $\left(\mathrm{T}_{\mathrm{D}}\right)$ temperatures, linear velocity $\left(\mathrm{v}_{\mathrm{L}}\right)$, split ratio, volume $(\mathrm{V})$ and oven final temperature $\left(\mathrm{T}_{\mathrm{F}}\right)$ were the experimental factors examined. The chromatographic conditions and the esters contents are presented in Table 7. Robustness $\left(\mathrm{R}_{\mathrm{o}}\right.$ ) was expressed as the relative standards deviation (RSD), and was found 1.1 and $0.1 \%$ to the methyl and ethyl biodiesel, respectively, assuring that those small parameters variations don't affect the results.

\section{CONCLUSION}

A GC-FID method for the determination of the esters content in biodiesel from two different feedstock, canola and soy, using hexadecyl acetate (HDA) as a new internal standard, was validated. Methyl and ethyl biodiesel from both feedstocks were assayed. Different from other internal standards as heptadecanoic or nonadecanoic acids derivatives, hexadecyl acetate is unnatural, and surely absent from any feedstock biodiesel. The new methodology was evaluated for methyl and ethyl biodiesel derivated from canola and soy oils. In both cases, HDA peak was observed well resolved. Method selectivity, accuracy, repeatability, intermediate precision, and robustness were evaluated and considered appropriate for the scope.

\section{ACKNOWLEDGEMENTS}

FAPERGS, CNPq, and CAPES.

\section{REFERENCES}

1. BP Energy Outlook, 2017 edition, http://www.bp.com/content/dam/bp/ pdf/energy-economics/energy-outlook-2017/bp-energy-outlook-2017. pdf, accessed in July 2017.
2. Balanço energético Nacional 2016 - Ano base 2015: Relatório Síntese, EPE: Rio de Janeiro, 2016.

3. Abbaszaadeh, A.; Ghobadian, B.; Omidkhah, M. R.; Najafi, G.; Energy Convers. Manage. 2012, 63, 138.

4. Demirbas, A.; Energy Convers. Manage. 2008, 49, 2106.

5. Demirbas, A.; Demirbas, I.; Energy Convers. Manage. 2007, 48, 2386.

6. Demirbas, A.; Prog. Energy Combust. Sci. 2007, 33, 1.

7. Pousa, G. P. A. G;. Santos, A. L. F.; Suarez, P. A. Z.; Energy Policy 2007, 35, 5393.

8. Cremonez, P. A.; Feroldi, M.; Nadaleti, W. C.; de Rossi, E.; Feiden, A.; de Camargo, M. P.; Cremonez, F. E.; Klajn, F. F.; Renewable Sustainable Energy Rev. 2015, 42, 415.

9. Rico, J. A. P.; Sauer, I. L.; Renewable Sustainable Energy Rev. 2015, 45, 513.

10. http://www.anp.gov.br/wwwanp/dados-estatisticos, accessed in July 2017.

11. https://www.statista.com/statistics/271472/biodiesel-production-inselected-countries/, accessed in July 2017.

12. Knothe, G.; Fuel Process. Technol. 2005, 86, 1059.

13. Knothe, G.; Energy Fuels 2008, 22, 1358.

14. Schuchardt, U.; Sercheli, R.; Vargas, R. M.; J. Braz. Chem. Soc. 1998, 9, 199 .

15. Pinto, A. C.; Guarieiro, L. L. N.; Rezende, M. J. C.; Ribeiro, N. M.; Torres, E. A.; Lopes, W. A.; Pereira, P. A. P.; de Andrade, J. B.; J. Braz. Chem. Soc. 2005, 16, 1313.

16. de Oliveira, D. M.; Ongaratto, D. P.; Fontoura, L. A. M.; Naciuk, F. F.; dos Santos, V. O. B.; Kunz, J. D.; Marques, M. V.; de Souza, A. O.; de Pereira, C. M. P.; Samios, D.; Quim. Nova 2013, 36, 734.

17. Boletim Mensal do Biodiesel 2017 - fevereiro, http://www.anp.gov. br/wwwanp/images/publicacoes/boletins-anp/Boletim_Mensal_do_ Biodiesel/2017/Boletim_Biodiesel_FEVEREIRO_2017.pdf, accessed in July 2017.

18. Pitts, S. J.; Thomson, C. I.; J. Forensic Sci. 2003, 48, 1.

19. Resolução ANP de 25/08/2014, https://www.legisweb.com.br/ legislacao/?id=274064, accessed in July 2017.

20. EN 14103:2011; Fatty acid methyl esters (FAME) - Determination of ester and linolenic acid methyl ester contents. European Committee for Standardization: Brussels, 2011. 
21. ABNT NBR 15764; Biodiesel - Determinação do teor total de ésteres por cromatografia gasosa. Associação Brasileira de Normas Técnicas: Rio de Janeiro, 2015.

22. Knothe, G.; J. Am. Oil Chem. Soc. 2006, 83, 823.

23. Monteiro, M. R.; Ambrozin, A. R. P.; Lião, L. M.; Ferreira, A. G.; da Cruz, R. S.; Talanta 2008, 77, 593.

24. Lôbo, I. P.; Ferreira, S. L. C.; Quim. Nova 2009, 32, 1596.

25. Issariyakul, T.; Dalai, A. K.; Renewable Sustainable Energy Rev. 2014, $31,446$.

26. Wang, Y.; Ou, S.; Liu, P.; Xue, F.; Tang, S.; J. Mol. Catal. A: Chem. 2006, 252, 107.

27. Moraes, M. S. A.; Krause, L. C.; da Cunha, M. E.; Faccini, C. S.; de Menezes, E. W.; Veses, R. C.; Rodrigues, M. R. A.; Caramão, E. B.; Energy Fuels 2008, 22, 1949.

28. Milinsk, M. C.; Matsushita, M.; Visentainer, J. V.; de Oliveira, C. C.; de Souza, N. E.; J. Braz. Chem. Soc. 2008, 19, 1475.

29. da Cunha, M. E.; Krause, L. C.; Moraes, M. S. A.; Faccini, C. S.; Jacques, R. A.; Almeida, S. R.; Rodrigues, M. R. A.; Caramão, E. B.; Fuel Process. Technol. 2009, 90, 570.

30. de Moura, C. V. R.; de Castro, A. G.; de Moura, E. M.; dos santos Jr., J. R.; Energy Fuels 2010, 24, 6527.

31. Marques, M. V.; Naciuk, F. F.; Mello, A. M. S.; Seibel, N. M.; Fontoura, L. A. M.; Quim. Nova 2010, 33, 978.

32. Faria, F. D.; Cerqueira, K. O.; Leal, G. P.; Pereira, R. C. L.; Neto, M. J. R. G.; J. ASTM Int. 2010, 7, 181

33. Prados, C. P.; Rezende, D. R.; Batista, L. R.; Alves, M. I. R.; Antoniosi Filho, N. R.; Fuel 2012, 96, 476.

34. Carvalho, M. S.; Mendonça, M. A.; Pinho, D. M. M.; Resck, I. S.; Suarez P. A. Z.; J. Braz. Chem. Soc. 2012, 23, 763.

35. Cunha Jr., A.; Feddern, V.; de Prá, M. C.; Higarashi, M. M.; de Abreu, P. G.; Coldebella, A.; Fuel 2013, 105, 228.

36. Singh, D.; Chopra, A.; Kumar, R.; Sastry, M. I. S.; Patel, M. B.; Basu, B.; Chromatographia 2014, 77, 165.

37. Mayo, C. M.; Alayon, A. B.; Rodriguez, M. T. G.; Abizanda, A. I. J.; Moreno; F. G.; Environ. Technol. 2015, 36, 1933.

38. Sobrado, L. A.; Freije-Carrelo, L.; Moldovan, M.; Encinar, J. R.; Alonso, J. I. G.; J. Chromatogr. A 2016, 1457, 134.

39. Sato, R. T.; Stroppa, P. H. F.; da Silva, A. D.; de Oliveira, M. A. L.; Quim. Nova 2016, 39, 352.

40. Musharraf, G.; Ahmed, M. A.; Zehra, N.; Anal. Methods 2015, 7, 3372.
41. Yuan, X.; Liu, J.; Zeng, G.; Shi, J.; Tong, J.; Huang, G.; Renewable Energy 2008, 33, 1678.

42. Pardo, v. L.; Fagundes, C. A. M.; Caldas, S. S.; Kurz, M. H.; Clementin, R. M.; D’Oca, M. G. M.; Primel, E. G.; J. Am. Oil. Chem. Soc. 2012, 89, 631.

43. Morales, V.; Goren, A. C.; Held, A.; Bilsel, M.; Gündüz, S.; Yilmaz, H.; Accredit. Qual. Assur. 2015, 20, 411.

44. Pasupuleti, D.; Eiceman, G. A.; Pierce, K. M.; Talanta 2016, 155, 278.

45. Arruda, T. B. M. G.; Rodrigues, F. E. A.; Arruda, D. T. D.; Ricardo, N. M. P. S.; Dantas, M. B.; de Araújo, K. C.; Ind. Crops Prod. 2016, 91, 264.

46. Goodman, M. R.; Kaley, E. A.; Finney, E. E.; Forensic Sci. Int. 2016, $263,10$.

47. Holcapek, M.; Jandera, P.; Fischer, J.; Prokes, B.; J. Chromatog. A 1999, 858, 13.

48. Fedosov, S. N.; Fernandes, N. A.; Firdaus, M. Y.; J. Chromatog. A 2014 1326,56

49. dos Santos, B. L.; da Silva, K. K.; dos Santos, A. P. F.; de Andrade, D. F.; d'Avila, L. A.; J. Liq. Chromatogr. Relat. Technol. 2016, 39, 620.

50. Chattopadhyay, S.; Das, S.; Sem, S.; Appl. Energy 2011, 88, 5188.

51. Mello, V. M.; Oliveira, F. C. C.; Fraga, W. G.; do Nascimento, C. J.; Suarez, P. A. Z.; Magn. Reson. Chem. 2008, 46, 1051.

52. Guzatto, R.; Martini, T. L.; Samios, D.; Fuel Process. Technol. 2011, 92 , 2083.

53. Guzzato, R.; Samios, D.; Defferrari, D.; Reinznautt, Q. B.; Cadore, I. R.; Fuel Process. Technol. 2012, 92, 197.

54. Visentainer, J. V.; Quim. Nova 2012, 35, 274.

55. Ribani, M.; Bottoli, C. B. G.; Collins, C. H.; Jardim, I. C. S. F.; Melo, L. F. C.; Quim. Nova 2004, 27, 771.

56. Cienfuegos, F.; Estatística Aplicada ao Laboratório, $1^{\text {a }}$ ed., Interciência: Rio de Janeiro, 2005.

57. Karageorgou, E.; Samanidou, V.; J. Chromatogr. A 2014, 1353, 131.

58. Snyder, L. R.; Kirkland, J. J.; Glajch, J. L.; Practical HPLC Method Development, $2^{\text {nd }}$ ed., Wiley: New York, 1997.

59. Orientação sobre Validação de Métodos de Ensaios Químicos, DOQ-CGCRE-008 Revisão 04, Instituto Nacional de Metrologia, Normalização e Qualidade Industrial, 20011. http://www.inmetro.gov. br/Sidoq/Arquivos/Cgcre/DOQ/DOQ-Cgcre-8_04.pdf, accessed in July 2017. 